\title{
Powder properties of binary mixtures of chloroquine phosphate with lactose and dicalcium phosphate
}

\author{
Michael Ayodele Odeniyi*, Collins Chidi Onyenaka, Oludele Adelanwa Itiola
}

Department of Pharmaceutics \& Industrial Pharmacy, Faculty of Pharmacy, University of Ibadan, Nigeria

\begin{abstract}
A study was conducted on the packing and cohesive properties of chloroquine phosphate in binary mixtures with lactose and dicalcium phosphate powders. The maximum volume reduction due to packing as expressed by the Kawakita constant, a, and the angle of internal flow, $\theta$, were the assessment parameters. The individual powders were characterized for their particle size and shape using an optical microscope. Binary mixtures of various proportions of chloroquine phosphate with lactose and dicalcium phosphate powders were prepared. The bulk and tapped densities, angles of repose and internal flow, as well as compressibility index of the materials were determined using appropriate parameters. The calculated and determined values of maximum volume reduction for the binary mixtures were found to differ significantly $(\mathrm{P}<0.05)$, with the Kawakita plot being more reliable in determining the packing properties. Diluent type was found to influence the flow properties of the mixtures, with dicalcium phosphate giving predictable results while mixtures containing lactose were anomalous with respect to flow. The characterization of the packing and cohesive properties of the binary mixtures of chloroquine with lactose and dicalcium phosphate would be useful in the production of powders, tablets, capsules and other drug delivery systems containing these powders with desirable and predictable flow properties.
\end{abstract}

Uniterms: Chloroquine phosphate. Lactose. Dicalcium phosphate. Drugs/delivery systems. Drugs/ production. Drugs/packing/ characterization.

Realizou-se estudo das propriedades de empacotamento e de coesão do fosfato de cloroquina em misturas binárias com lactose e fosfato dicálcico em pó. O volume máximo de redução devido ao empacotamento, segundo expresso pela constante de Kawakita, a, e o ângulo de fluxo interno, $\theta$, foram os parâmetros de avaliação. Os pós individuais foram caracterizados por seu tamanho e forma de partículas, utilizando microscópio óptico. Prepararam-se misturas binárias de várias proporções de fosfato de cloroquine e lactose e fosfato dicálcico em pó. As densidades de bulk and tapped, os ângulos de repouso e de fluxo interno e o índice de compressibilidade dos materiais foram determinados utilizando-se parâmetros apropriados. Os valores calculados e determinados do volume máximo de redução para as misturas binárias mostraram-se significativamente diferentes $(\mathrm{P}<0,05)$, sendo o traçado de Kawakita mais confiável na determinação das propriedades de empacotamento. O tipo de diluente influenciou as propriedades de fluxo das misturas com fosfato dicálcico, dando resultados previsíveis, enquanto as misturas contendo lactose mostraram-se anômalas com relação ao fluxo. A caracterização das propriedades de empacotamento e de coesão das misturas binárias de cloroquina com lactose e fosfato dicálcico seria útil na produção de pós, comprimidos, cápsulas e outros sistemas de liberação de fármacos contendo esses pós com propriedade de fluxo desejada e previsível.

Unitermos: Fosfato de cloroquina. Lactose. Fosfato dicálcico. Fármacos/sistemas de liberação. Fármacos/ produção. Fármacos/empacotamento/caracterização.

*Correspondence: M. A. Odeniyi. Department of Pharmaceutics \& Industrial Pharmacy, Faculty of Pharmacy, University of Ibadan, Nigeria. E-mail: deleodeniyi@yahoo.com 


\section{INTRODUCTION}

The packing and cohesive properties of powders are highly relevant in the course of powder mixing, filling of capsules with powders or granules, and filling of dies during tabletting operation. (Podczeck, Sharma, 1996). The influence of particle size, particle size distribution and shape has been observed in previous studies to determine the flow and compressibility properties of particles (Ahineck, Alderborn, 1989; Karehill et al., 1990; Odeniyi et al., 2008). Since most particles are not spherical or regularly shaped, particle shape is described by a scalar quantity known as shape factor or shape coefficient. This serves as a proportionality constant between mean particle diameter and particle surface area and volume. Shape coefficient also serves in comparing results from experimental particle size measurements by different methods.

Several models proposed for characterizing the behaviour of binary powder mixtures have been limited in that spherical shape is necessary for their validation (Westman, Hugill, 1932) or because they have addressed only a narrow particle size fraction (Newton, Bader, 1981) or the predictive power is lost with additional powder component (Staple, 1975).

However, simple tapping experiments have been found useful in order to quantify the packing and cohesive properties of powders. Of importance in this regard is the Kawakita function which can be used to relate the degree of volume reduction to applied pressure for single powders and powder mixtures. The function has been used in connection with compaction under high loads, but also in the following form to study the volume reduction of a powder or powder mixture due to tapping (Itiola, Odeku, 2005; Odeniyi et al., 2008).

$$
\begin{gathered}
\mathrm{N} / \mathrm{C}=1 / \mathrm{a} \cdot \mathrm{N}+1 / \mathrm{ab} \\
\mathrm{C}=\left(\mathrm{V}_{\mathrm{o}}-\mathrm{V}_{\mathrm{N}}\right) / \mathrm{V}_{\mathrm{O}}
\end{gathered}
$$

and

$$
\mathrm{a}=\left(\mathrm{V}_{\mathrm{o}}-\mathrm{V}_{\infty}\right) / \mathrm{V}_{\mathrm{O}}
$$

where $a$ and $b$ are constants characterizing the material, $\mathrm{N}$ is the number of taps, $\mathrm{C}$ represents the degree of volume reduction achieved after $\mathrm{N}$ taps, $\mathrm{V}_{\mathrm{o}}$ is the maximum bulk volume of the powder, $\mathrm{V}_{\mathrm{N}}$ is the bulk volume of the powder after $\mathrm{N}$ taps, and $\mathrm{V}_{\infty}$ is the minimum bulk volume. The constant $a$ has practical application for powders since it describes the maximal possible relative decrease in the initial bulk volume due to tapping.
However, while the parameter $a$ can be obtained from equation $3, \mathrm{~V}_{\infty}$ may be more difficult to determine from tapping procedures [1]. Further, $a$ can be determined with significant accuracy from the slope of the linear plot of $\mathrm{N} / \mathrm{C}$ versus $\mathrm{N}$ in Equation 1. Hence, the determination of $a$ does not depend on $\mathrm{V}_{\infty}$. Another parameter useful in determining the characteristics of powders and derivable from simple tapping experiments is the angle of internal flow $(\theta)$. This is a direct measure of the cohesiveness of powders. This is obtained from plots using the decreasing porosity (E) of a powder with increasing number of taps, N. A linear relationship was observed by Varthalis and Pilpel (1976) between $\mathrm{E}$ and $\mathrm{N}$ of the form:

$$
E^{2} \mathrm{~N} / 1-\mathrm{E}=\mathrm{K}
$$

Plots of $\mathrm{K}$ against $\mathrm{N}$ would give values of $\mathrm{K}_{\mathrm{o}}$ as intercepts. These are constant for each powder or powder mixture. $\mathrm{K}_{\mathrm{o}}$ describes the powder before any tappings and can be employed to determine the angle of internal flow of the powder after tapping. This is due to the fact that the cohesiveness of a powder is a measure of the resistance to flow when tapped or compressed. Plots of $\mathrm{K}-\mathrm{K}_{\mathrm{o}}$ against $\mathrm{N}$ would give the values of $\tan \theta$ and values of angle of internal flow of the powder obtained from the inverse.

While powder properties have been described using the various parameters described, it has proven difficult to predict the properties of mixtures from the properties of the individual powders. Also, an interaction has been observed between particles size and shape on packing and densification of powders (Shotton, Obiorah, 1973). Hence, the objective of the present study was to determine specific packing and cohesive properties of chloroquine phosphate, a common antimalarial drug, in binary mixtures with lactose and dicalcium phosphate (DCP) which are diluents used in its formulation as a tablet. The study also sought to establish the influence of method of obtaining the parameter ' $a$ ' using tapping procedures and through derivation from the Kawakita equation.

\section{MATERIALS AND METHODS}

\section{Materials}

The powders used were chloroquine phosphate (Bayer, Germany), lactose B.P. (DVM, Veghel, Holland) and dicalcium phosphate (Rhodia Inc, USA).

\section{Characterization of the powders}

An optical microscope was used to determine the particle size distribution and shape of the powders, with 
approximately 300 particles for each powder, and the mean projected particle diameters (d) for the different powder mixtures were calculated from the values obtained. Also, particle densities of the individual powders were determined by the pycnometer method with xylene as the displacement fluid.

The shape factor (shape coefficient), $\alpha$, of the particles of each powder was calculated from the expression:

$$
\alpha=\operatorname{Sw} \rho_{\mathrm{s}} \mathrm{d}_{\mathrm{e}}+\mathrm{R}
$$

where $\mathrm{Sw}$ is the specific surface area of the particles $\left(\mathrm{m}^{2} . \mathrm{g}^{-1}\right)$ which was determined from the size distribution of the particles; de is the Heywood equivalent diameter $(\mu \mathrm{m})$ and is expressed as:

$$
d_{e}=\frac{(4 \times 0.77 \times L \times B)^{1 / 2}}{(\pi)}
$$

Where $\mathrm{R}$, the elongation ratio is $\mathrm{L} / \mathrm{B}$; and $\mathrm{L}$ and $\mathrm{B}$ are the arithmetic mean values of the particle length and breadth respectively; $\rho_{\mathrm{s}}$ is the particle density $\left(\mathrm{g} . \mathrm{cm}^{-3}\right)$ of each powder. The values of the projected mean diameter $\delta$ are presented in Table I.

\section{Determination of volume and density parameters}

In determining the initial bulk volume, $\mathrm{V}_{\mathrm{o}}, 20 \mathrm{~g}$ each of the powders was poured at an angle into a glass cylinder and the volume of the untapped bulk determined. The powders were then subjected to various numbers of taps in the cylinder according to British Standard 1460 (38 taps per minute). Values of bulk volume $\left(\mathrm{V}_{\mathrm{N}}\right)$ for the powders were determined at intervals of 25 taps, and values of bulk density were calculated using the weight of the powders. The solid fraction $\left(\mathrm{S}_{\mathrm{f}}\right)$ values of the powders were then obtained from the ratios of the bulk density to the particle density. Determinations were made in quadruplicate.
Binary mixtures of chloroquine phosphate powder with lactose and dicalcium phosphate were prepared by first weighing the smaller proportion into a dry bottle and then turning the bottle from side to side to ensure mixing. The compositions of each of the mixtures are given in Table II.

\section{Determination of angle of repose}

The flow properties of the individual powders and the binary mixtures of chloroquine phosphate with lactose and dicalcium phosphate were investigated by measuring their angle of repose. Twenty grammes of the different powders and powder mixtures were poured into an open-ended glass cylinder with a diameter of $2.8 \mathrm{~cm}$. On raising the cylinder, the powder flowed out and formed a conical heap. The height of the cone was measured and the angle of repose $(\theta)$ is given by the equation:

$$
\Theta=\tan ^{-1}(\mathrm{~h} / \mathrm{r})
$$

Where $\mathrm{h}$ is the height of conical powder heap and $\mathrm{r}$ is the radius of the circular base $(\mathrm{cm})$. The determinations were made in triplicate.

\section{Determination of the maximum volume reduction and} the compressibility index

Values of the reciprocal slope and the intercept of the plots of $\mathrm{N} / \mathrm{C}$ against $\mathrm{N}$ were obtained for all samples and used for the calculation of constants ' $a$ ' (maximum volume reduction) and 'b' (compressibility index) which are properties characterizing the powders.

\section{Determination of angle of internal flow}

The angle of internal flow was determined from equation 4, with the values of $\mathrm{k}_{\mathrm{o}}$ as intercepts. Subsequently, $\mathrm{k}-\mathrm{k}_{\mathrm{o}}$ was plotted against $\mathrm{N}$. The slopes of the plots gave $\tan \theta$, which is the angle of internal flow of the

\begin{tabular}{|c|c|c|c|c|c|c|}
\hline Powder & 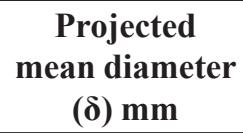 & $\begin{array}{l}\text { Particle } \\
\text { density } \\
\left(\text { g.cm }^{-3}\right)\end{array}$ & $\begin{array}{c}\text { Heywood } \\
\text { equivalent } \\
\text { diameter, de }\end{array}$ & $\begin{array}{c}\text { Elongation } \\
\text { ratio, } \mathbf{N}\end{array}$ & $\begin{array}{c}\text { Specific } \\
\text { Surface area, } \\
\mathbf{S}_{w},\left(\mathbf{m}^{2} / \mathrm{g}\right)\end{array}$ & $\begin{array}{c}\text { Shape } \\
\text { coefficient } \infty\end{array}$ \\
\hline $\begin{array}{l}\text { Chloroquine } \\
\text { phosphate }\end{array}$ & 9.5 & 1.580 & 33.81 & 2.19 & $4.9 \times 10^{10}$ & 4.82 \\
\hline Lactose & 3.5 & 1.545 & 45.05 & 1.27 & $7.27 \times 10^{10}$ & 1.73 \\
\hline $\begin{array}{l}\text { Dicalcium } \\
\text { phosphate }\end{array}$ & 2.8 & 2.900 & 22.90 & 1.64 & $4.93 \times 10^{10}$ & 2.14 \\
\hline
\end{tabular}
powders.

TABLE I - Particle and geometric properties of individual powders 
TABLE II - Percentage maximum reduction in volume due to tapping 'a' determined and calculated and index of compressibility 'b' for chloroquine/lactose (CQ:LAC) and chloroquine/dicalcium phosphate (CQ:DCP) binary mixtures

\begin{tabular}{lccccc}
\hline Mixture Code & $\begin{array}{c}\text { Binary Mixtures } \\
\text { CQ:LAC }\end{array}$ & 'a' determined (\%) & 'a' calculated (\%) & Percentage difference & 'b' \\
\hline A1 & $100: 0$ & 19.44 & 28.40 & 8.96 & 0.011 \\
A2 & $80: 20$ & 29.48 & 32.34 & 2.86 & 0.019 \\
A3 & $60: 40$ & 29.88 & 41.83 & 11.95 & 0.011 \\
A4 & $50: 50$ & 31.03 & 41.83 & 10.80 & 0.040 \\
A5 & $40: 60$ & 32.98 & 45.24 & 12.08 & 0.025 \\
A6 & $20: 80$ & 33.67 & 42.24 & 8.57 & 0.018 \\
A7 & $0: 100$ & 41.12 & 46.84 & 5.72 & 0.018 \\
\hline & CQ:DCP & & & & 0.011 \\
B1 & $100: 0$ & 19.44 & 28.40 & 8.96 & 0.006 \\
B2 & $80: 20$ & 21.12 & 24.85 & 3.73 & 0.021 \\
B3 & $60: 40$ & 26.58 & 29.92 & 3.34 & 0.009 \\
B4 & $50: 50$ & 30.03 & 30.41 & 0.38 & 0.009 \\
B5 & $40: 60$ & 30.08 & 30.48 & 0.4 & 0.005 \\
B6 & $20: 80$ & 21.79 & 24.35 & 2.56 & 0.010 \\
B7 & $0: 100$ & 33.75 & 49.72 & 13.68 & \\
\hline
\end{tabular}

\section{RESULTS AND DISCUSSION}

It can be observed that the particles of chloroquine powder were the largest, with dicalcium phosphate powders having the smallest projected mean diameter (Table I). This suggests that the binary mixtures of chloroquine phosphate-lactose will show increased porosity with increased lactose in the mixture. The ranking order of shape coefficient for the powders were chloroquine phosphate $>$ dicalcium phosphate $>$ lactose. The influence of shape factor is not usually clear cut as the shape can affect the powder properties in various ways depending on how the powders fit together in mixtures containing various proportions of the individual powders (Podczcek, Sharma, 1996). Also, strong binding properties of some powders have been adduced to their rough surfaces (Gustafsson et al., 2003; Nystrom et al.,1993).

The highest particle density was observed with dicalcium phosphate. Generally, high particle density has been found to favor free flow of powders (Yamashiro et al., 1983), therefore an increase in Dicalcium phosphate in the binary mixtures is expected to improve the flow properties of the mixture due to its influence on gravity and surface forces. This was not however observed in the binary mixtures prepared and this finding agrees with those of previous authors (Shotton, Obiorah, 1973; Yamashiro et al., 1983; Odeniyi et al., 2008) showing that when po- wders are mixed in different proportions, the properties of the mixtures may not be proportionally intermediated between those of the constituent powders. This anomalous behaviour has been ascribed to changes that occur in the packing arrangement of the powder particles.

Figure 1 compares the plots of the N/C values versus number of taps for the binary mixtures of the two diluents with Chloroquine phosphate at 20:80 drug:diluent ratio. The values of maximum volume reduction ' $a$ ' were obtained from the slopes of the plots. Table II presents the values of maximum volume reduction ' $a$ ' and index of compressibility ' $b$ '. The percentage difference between the two $a$ values are also given in the table. The results confirm those reported by the earlier study of Odeniyi et al. (2008) demonstrating that values obtained through the use of the Kawakita equation are more reliable. This is adduced to the fact that values of $a$ are not dependent on reaching the minimum bulk volume because the Kawakita function is linear as expressed in Equation (1), and thus the slope of the function will not change (Podczeck, Sharma, 1996). Also, from the results, it can be observed that dicalcium phosphate had the highest value of 'a' while chloroquine phosphate had the lowest maximum volume reduction after tapping. For the binary mixtures, the highest value of 'a' was observed for the chloroquine phosphate and lactose mixture at $60 \%$ concentration of the latter, while for the mixtures containing chloroquine phosphate and dicalcium 
phosphate, the highest volume reduction was also obtained at $60 \%$ concentration of the diluent. These results suggest that irrespective of particle size and shape, the optimum concentration in the binary mixtures was that in which chloroquine phosphate is $40 \%$. As outlined earlier, the fact that chloroquine phosphate powder had the largest projected mean diameter, which was much larger than the diluents, could account for it being the determining factor for volume reduction. This is of importance as even small differences in particle size and shapes have been observed to have significant influence on the flow properties of powder and powder mixtures (Byrne et al., 2002).

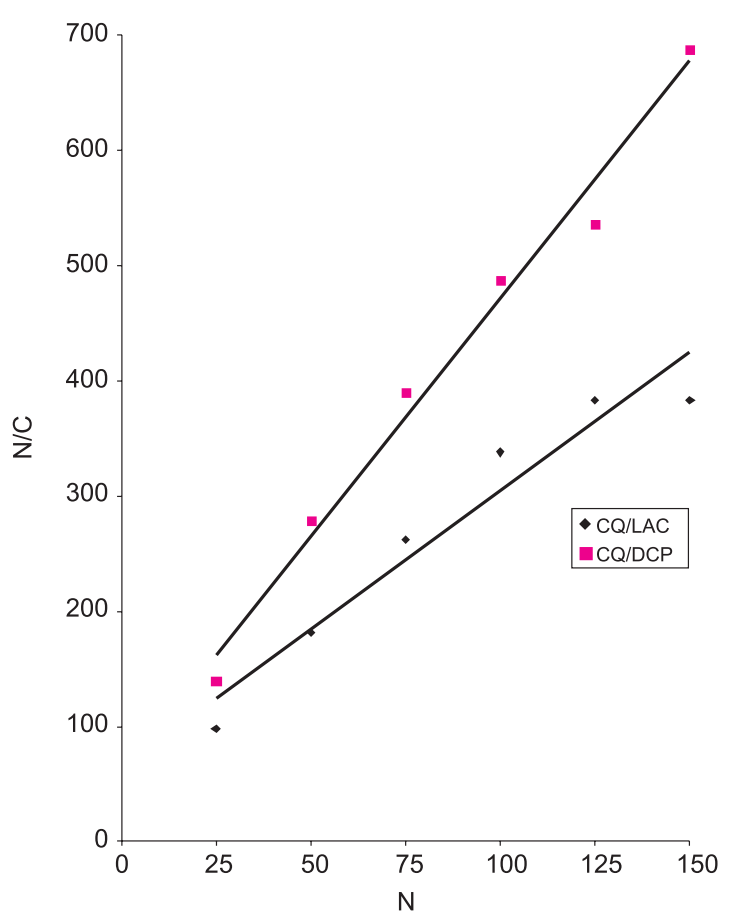

FIGURE 1 - Plots of N/C versus number of taps $\mathrm{N}$ for the binary mixtures of chloroquine phosphate $(\mathrm{CP})$ with lactose (LAC) and dicalcium phosphate (DCP) at a ratio of 20:80

Figures 2 and 3 compare the changes in the value of constants a, a' and angle of internal flow $\theta$ as a function of diluent content in the binary mixtures of chloroquine phosphate with dicalcium phosphate and lactose respectively.

In Figure 2, the influence of the concentration of dicalcium phosphate on the powder properties of its binary mixture with chloroquine phosphate is depicted. For both the $a$ determined and $a$ ' calculated there was an initial increase in the volume reduction with increasing amounts of dicalcium phosphate in the mixture, up to a concentration of $60 \% \mathrm{w} / \mathrm{w}$ DCP. However, a decrease was exhibited with increasing amount of the diluent with a final increase after

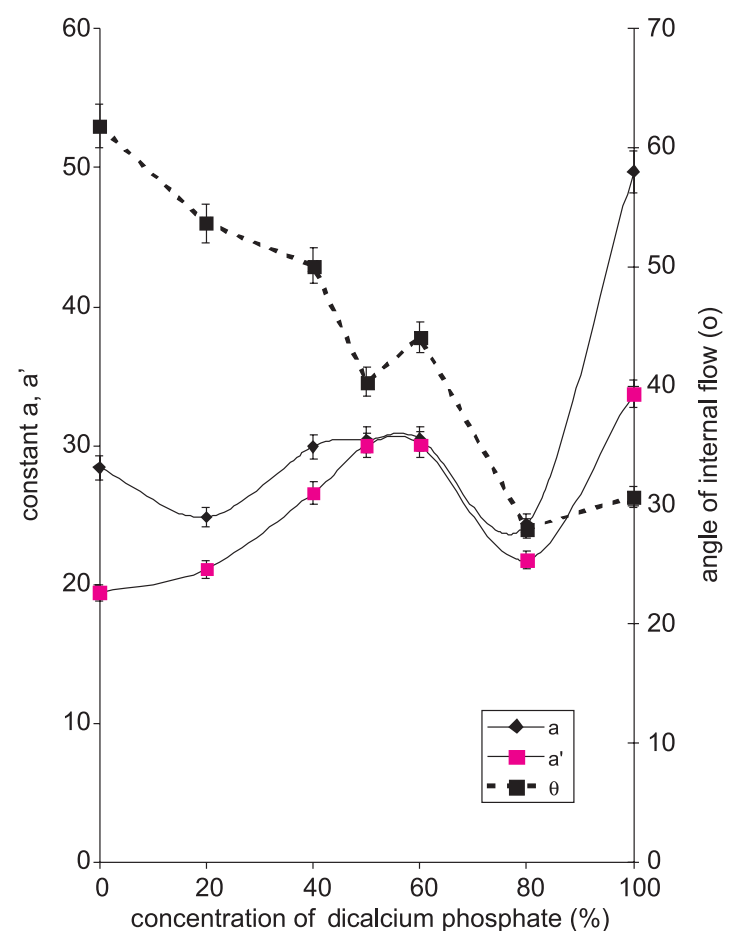

FIGURE 2 - Powder characteristics as a function of the concentration of dicalcium phosphate in binary mixtures with chloroquine phosphate

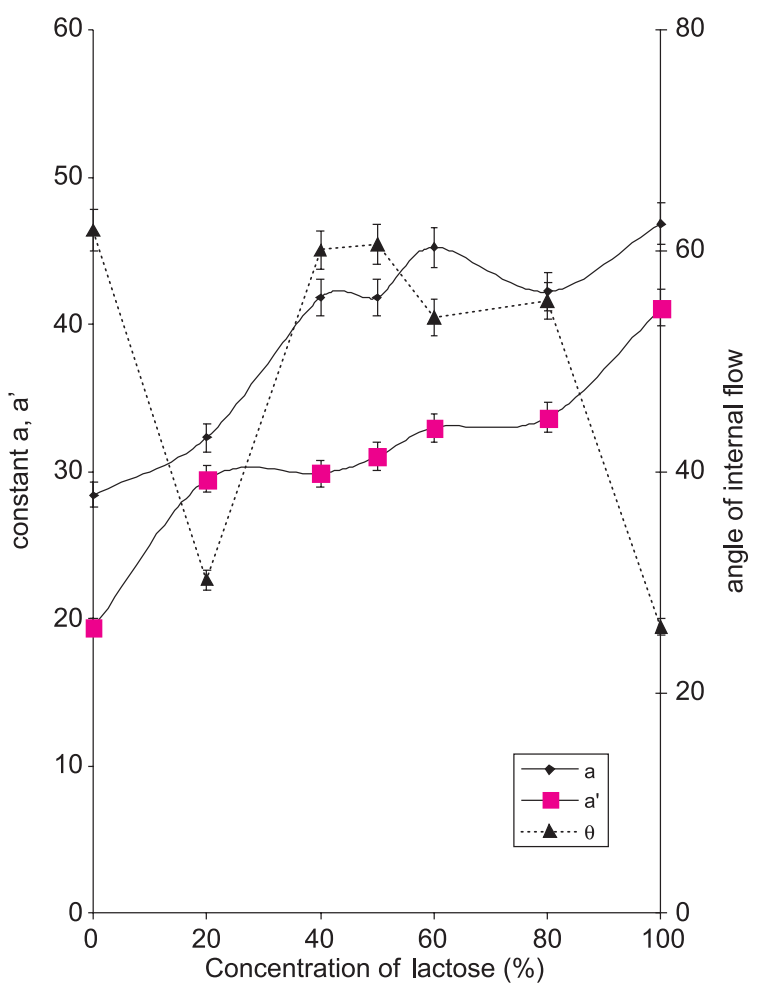

FIGURE 3 - Powder characteristics as a function of the concentration of lactose in binary mixtures with chloroquine phosphate 


\section{$80 \% \mathrm{w} / \mathrm{w}$ DCP.}

The angle of internal flow $\theta$, obtained from the slopes of the plots of K-Ko against number of taps N (Figure 4) was found to generally decrease with increasing concentration of DCP. This parameter provides a measure of the cohesiveness of the individual and powder mixtures (Itiola, Pilpel, 1996). Hence, the flow properties of the powder mixture were found to increase with an increase in the proportion of DCP in the mixture.

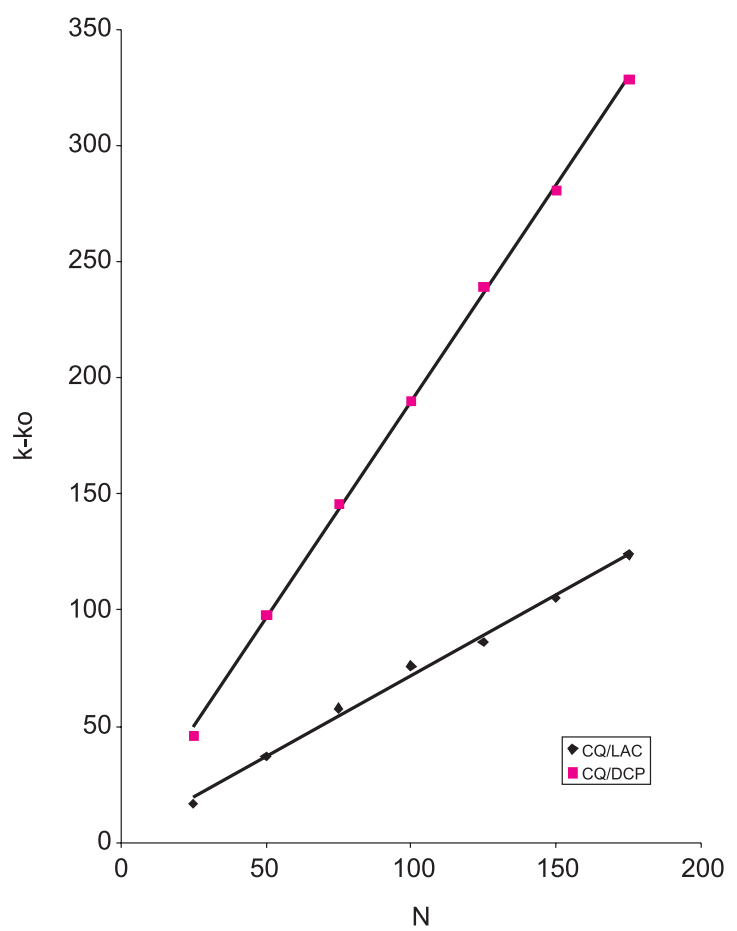

FIGURE 4 - Plots of (K-Ko) versus number of taps N of chloroquine phosphate (CQ) with lactose (LAC) and dicalcium phosphate (DCP) at a ratio of 20:80.

However, for the binary mixture of chloroquine phosphate and lactose, values of $a$ and $a$ ' were found to generally increase with increasing proportion of the diluent with significant $(P<0.05)$ differences in the determined and calculated values of volume of maximum reduction. Also, Figure 3 shows an anomalous behaviour of the powder mixture with regards to angle of internal flow. This indicates that while increase in lactose concentration caused increase in the maximum volume reduction, it was not predictive for the flow behaviour of the mixture.

\section{CONCLUSIONS}

The obtained results showed the influence of each diluent on the compression and flow properties of binary mixtures of chloroquine phosphate with dicalcium phos- phate and lactose. Particle shape and size were found to influence the volume reduction due to packing, represented by the Kawakita constant $a$, while the diluent type was found to influence the flow properties as measured by the angle of internal flow. However, while the proportion of dicalcium phosphate was predictive of the flow properties of the binary mixture, lactose exhibited anomalous behaviour. These results could be of use in determining the proportion and type of diluent in the processing of these powders in the production of powders, tablets, capsules and other drug delivery systems incorporating these powders.

\section{REFERENCES}

AHINECK, C.; ALDERBORN, G. Moisture absorption and tabletting; Effect of volume reduction properties and tablet strength for some crystalline materials. Int. J. Pharm., v.54, p.131-141, 1989.

BYRNE, E.; FITZPATRICK, J. J.; PAMPEL, L. W.; TITCHENER-HOOKER, N. J. Influence of shear on particle size and fractal dimension of whey protein precipitates: implications for scale-up and centrifugal clarification efficiency. Chem. Eng. Sci., v.57, n.18, p.37673779, 2002.

GUSTAFSSON, C.; LENNHOLM, H.; IVERSEN, T.; NYSTRÖM, C. Evaluation of surface and bulk characteristics of cellulose I powders in relation to compaction behaviour and tablet properties. Drug Dev. Ind. Pharm., v.29, p.1095-1107, 2003.

KAREHILL, P.G.; GLAZER M.; NYSTROM, C. Studies on direct compression of tablets. XXIII. The importance of surface roughness for compatibility of some directly compressible materials with different bonding and volume reduction properties. Int. J. Pharm., v.64, p.35-43, 1990.

ITIOLA, O.A.; ODEKU, O.A. Packing and cohesive properties of some locally extracted starches. Trop. J. Pharm. Res., v.4, p.363-368, 2005.

ITIOLA, O.A.; PILPEL, N. Effects of interacting variables on the disintegration and dissolution of metronidazole tablets. Pharmazie, v.51, p.987-989, 1996.

NEWTON, J.M.; BADER, F. The prediction of the bulk densities of powder mixtures, and its relationship to the filling of hard gelatin capsules. J. Pharm. Pharmacol., v.33, p.621-626, 1981. 
NYSTRÖM, C.; ALDERBORN, G.; DUBERG, M.; KAREHILL, P.-G. Bonding surface area and bonding mechanism - two important factors for the understanding of powder compactability. Drug Dev. Ind. Pharm., v.19, p.2143-2196, 1993.

ODENIYI, M.A.; ABOBARIN, T. O.; ITIOLA, O. A. Compressibility and flow characteristics of binary mixtures of metronidazole with lactose and microcrystalline cellulose. Farmacia, v.56, p.625-638, 2008.

PODCZECK, F.; SHARMA, M. The influence of particle size and shape of components of binary powder mixtures on the maximum volume reduction due to packing. Int. J. Pharm, v.137, p.41-47, 1996.
SHOTTON, E.; OBIORAH, B.A. The effect of particle shape and crystal habit on properties of Sodium chloride. $J$. Pharm. Pharmacol., v.25, 37P-43P, 1973.

STAPLE, W. J. The influence of size distribution on the bulk density of uniformly packed glass particles. Soil Sci. Soc. Am. Proc., v.39, p.404-408, 1975.WESTMAN, A.E.R.; HUGILL, H.R. The packing of particles. J. Am. Ceram. Soc., v.13, p.767-779, 1932.

YAMASHIRO, M.; YUASA, Y.; KAWAKITA, K. An experimental study on the relationship between compressibility, fluidity and cohesion of powder solids at small tapping numbers. Powder Tech., v.34, p.225-231, 1983.

Received for publication on $20^{\text {th }}$ February 2009 Accepted for publication on $03^{\text {rd }}$ March 2010 